\title{
Osaka Bay in Japan as a model for investigating the factors controlling temporal and spatial persistence among introduced marine and brackish species in a heavily industrialized harbor
}

\author{
Michio Otani ${ }^{1}{ }^{*}$ and Richard C. Willan ${ }^{2)}$ \\ 1) Osaka Museum of Natural History, 1-23 Nagaikoen, Higashi-sumiyoshi-ku, Osaka 564-0034, Japan \\ 2) Museum and Art Gallery of the Northern Territory, G.P.O. Box 4646, Darwin Northern Territory 0820, Australia \\ * Corresponding author: Michio Otani E-mail: michio-otani@h5.dion.ne.jp
}

(Received January 5, 2017; Accepted May 31, 2017; Published Online August 29, 2017)

\begin{abstract}
With five large and several small ports, Osaka Bay is heavily industrialized rendering the introduction of marine species that are not native to Japan inevitable. It presents, therefore, an ideal model locality to investigate the presence and persistence of introduced marine and estuarine species. We used the results obtained from surveys by citizen scientists undertaken between 2010 and 2013 to investigate the temporal and spatial patterns in numbers of introduced species. The results show remarkable temporal consistency in numerical diversity with between 11 and 15 introduced species being recorded every year. There were, however, strong spatial differences with tendencies for greater numbers of introduced species in the inner Bay and for lower numbers in the outer Bay. We analyzed the factors responsible for these patterns statistically using a generalized linear model (GLM). The optimal model implicated salinity and the number of native species. Because the salinity of Osaka Bay lies within the tolerance range of all the introduced species, it was discounted as a factor limiting introductions into the Bay. This implies that, interestingly, the actual number of native species is the most important limiting factor. This is then a real-world validation of the ecosystem resistance hypothesis.
\end{abstract}

Keywords: benthic intertidal organisms, generalized linear model, introduced species, spatial change, temporal change

\section{Introduction}

Ever since Charles Elton first highlighted the problem of introduced marine species in his seminal book The Ecology of Invasion by Animals and Plants (Elton, 1958), they have been recorded, one after another, all round the world, often accompanied by concern that they might become serious pests with major impacts on infrastructure, human health or the natural environment. The number of introduced species has continued to increase with the push towards a global economy. Indeed, there has been a dramatic increase in the number of introduced marine species accompanying the 14-fold growth in world trade since 1950 (Hayes, 2003). For example, as Cohen and Carlton (1998) documented in San Francisco Bay, in the United States of America, the rate of introduction has increased from an average of one new species established every 55 weeks between 1851 and 1960, to an average of one new species every 14 weeks between 1961 and 1995. Along with the rest of the world, the number of species introduced into Japan has also continued to increase, with the most dramatic change after the 1960s paralleling that of San Francisco Bay (Iwasaki et al., 2004; Otani, 2012).

While it is recognized that the number of introduced species is changing with time, it is also recognized that the number of species has changed in space as well. For example, Hewitt and Campbell (2010) showed that changes have occurred in the number of introduced marine species by bioregion (these observations being based on an IUCN document that divided the world's oceans into 18 bioregions). These changes may have been caused by differences in search effort and data quality, including the current state of taxonomic and biogeographic knowledge (Hewitt and Campbell, 2010; Ruiz et al., 2013). In addition, these changes may have been caused by differences in larval supply and the strength of biotic resistance by each bioregion (Wasson et al., 2005; Ruiz et al., 2013).

Furthermore, these changes are not only observed on the coarse scale of the bioregion, but they can also be observed at the finer regional scale (e.g. Wolff, 1999; Wasson et al., 2005; Preisler et al., 2009; Ruiz et al., 2013). It is suggested that these small scale changes along a particular coastline are the result of different conditions of the inoculated area of the introduced species, such as (a) hard substrata versus soft substrata, or (b) artificial coasts versus natural coasts, or (c) estuaries versus open coasts, or (d) the distance away from a harbor (Wasson et al., 2005; Preisler et al., 2009). This poses the question as to why these different conditions should control the differences between the numbers of introduced species. Naturally it is important to understand the reasons in order to set up countermeasures to prevent the introduction of 
yet more introduced species and minimize the impact the established ones cause.

So far, however, there are no studies in Japan relating the number of introduced species with particular attributes of the receiving coasts, either temporally or spatially. This indicates the lack of information to prevent invasions in Japan, as well as a dearth of information on the establishment and expansion of the introduced species. To make up for this lack of information in this country, we checked temporal and spatial changes of the number of introduced species in Osaka Bay, a heavily industrialized bay on the Pacific coast of the most populated island, Honshū. This Bay serves as a model for the enclosed marine waterways worldwide that are now industrialized. Changes for numbers in space were compared between different environments ranging from the open sea to the sheltered estuary in the inner Bay. Based on these results, we tried to elucidate the mechanisms responsible for these changes.

In this study, we analyzed data from three independent sources. We used data resulting from censuses of intertidal organisms (i.e., marine and brackish fishes, invertebrates, algae and vascular plants) undertaken by the Committee on Biological Surveys in Osaka Bay (see Ishida et al., 2015). In addition to these biotic data, the results of a survey of the Bay's water quality also form part of our analysis. These results were obtained by local governments. Furthermore, we included data on the number of ships arriving in the Bay from the Ministry of Land, Infrastructure, Transport and Tourism to give an idea of the potential arrival of introduced species in both ballast water and on ships' hulls.

Without doubt some planktonic organisms, like dinoflagellates, diatoms and ctenophores, must have been introduced into Osaka Bay as the result of discharge of ballast water from ships and some of these organisms can certainly have serious impacts on human health. For example, the supposedly introduced (but more probably cryptogenic) dinoflagellate Heterocapsa circularisquama Horiguchi, which causes toxic 'red tides', has been recorded from elsewhere in Japan (Horiguchi, 1995; Sato, 2002), but not in Osaka Bay in spite of the regular long-term plankton surveys undertaken by the Research Institute of Environment, Agriculture and Fisheries, Osaka Prefecture. For these reasons, we only had access to data on benthic species and we only consider them here.

\section{Materials and methods}

\section{Characterization of Osaka Bay}

Osaka Bay is a large enclosed embayment with an area of $1,450 \mathrm{~km}^{2}$ located a little to the west of the centre of Honshū island (Fig. 1). It opens through two narrow channels, one to the west and the other to the south. The former is the Akashi Channel that opens to the Seto Inland Sea and the latter is the Kitan Channel that opens to the Kii Channel. Three large

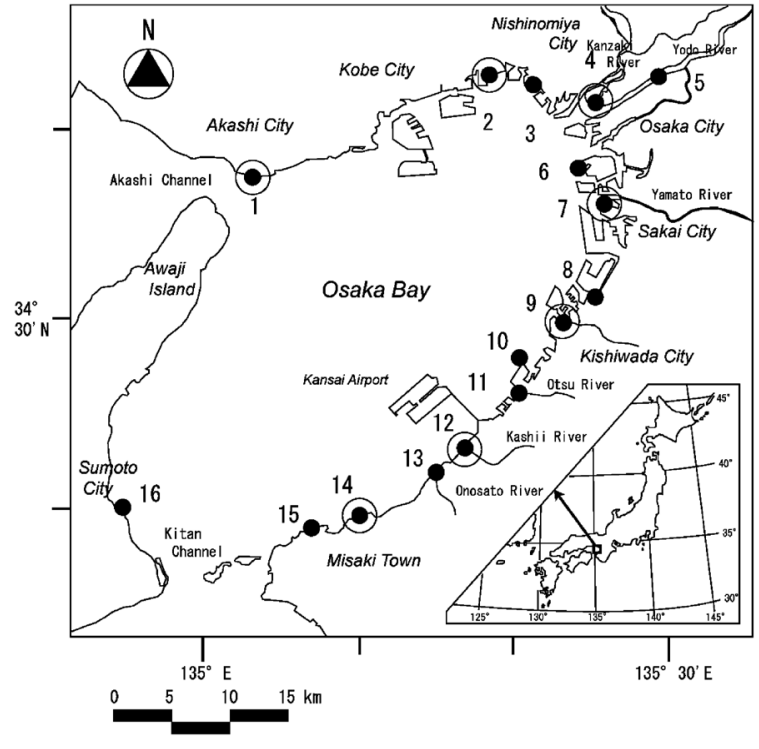

Fig. 1. Survey stations for intertidal organisms (solid circles) and stations used for GLM analysis (open circles) in Osaka Bay. Numerals next to circles represent station numbers.

rivers, the Yodo, the Yamato, and the Kanzaki, discharge into the inner Bay with an average of 85 hundred million tons of water a year entering annually (The environment database of Osaka Bay, http://kouwan.pa.kkr.mlit.go.jp/kankyo-db/data/ b109kasen).

On the other hand, oceanic water originating from the $\mathrm{Ku}$ roshio Current flows north past the western part of the Bay. This euhaline water is, however, diluted gradually towards the head of the Bay by river water derived from the three large rivers. Along the eastern coast of the Bay there is a residual current which flows from the inner Bay towards the Bay's mouth. Because the discharges from the three rivers mix with the residual current, the salinity of the eastern side of the Bay is lower than that of the western side.

The total coastline of Osaka Bay is $264.84 \mathrm{~km}$, of which artificial coastlines nowadays constitute $225.96 \mathrm{~km}(85.3 \%)$, natural and semi-natural coastlines constitute $21.93 \mathrm{~km}$ $(8.3 \%)$ and $11.73 \mathrm{~km}(4.4 \%)$, respectively, and river mouths constitute $5.22 \mathrm{~km}(2.0 \%)$ (Nature Conservation Bureau of the Environment Agency, 1998).

Large ports that account for most of the international and domestic shipping traffic, such as Kobe Port, Osaka Port, Amagasaki-Nishinomiya Port, Sakai-Senboku Port and Hannan Port, are located on the inner Bay. Other ports located along the eastern coast of the outer Bay cater for domestic ships or for fishing vessels. They have considerably less shipping traffic than the international ports in the inner Bay.

\section{Study area and sampling frequency}

The surveys for intertidal organisms within Osaka Bay summarized here were conducted between 2008 and 2013 at between 17 and 23 stations each year during the spring tides in May or June (see Ishida et al., 2015). The surveys were car- 
Table 1. Survey stations in Osaka Bay and their substrata (International ports are donated with an asterisk (*) and domestic ports have no asterisk).

\begin{tabular}{|c|c|c|c|c|c|}
\hline $\begin{array}{l}\text { Stn } \\
\text { No. }\end{array}$ & Station name (Location) & Latitude (N) & Longitude (E) & Substratum & $\begin{array}{c}\text { Port near the sampling station } \\
\text { for GLM analysis }\end{array}$ \\
\hline 1 & Azur Maiko & $34^{\circ} 37^{\prime} 37^{\prime \prime}$ & $135^{\circ} 02^{\prime} 28^{\prime \prime}$ & Cobble, Riprap seawall & Akashi Port \\
\hline 2 & Koroen Beach & $34^{\circ} 43^{\prime} 28^{\prime \prime}$ & $135^{\circ} 19^{\prime} 41^{\prime \prime}$ & Riprap seawall & Amagasaki-Nishinomiya Port ${ }^{*}$ \\
\hline 3 & Koshien Beach & $34^{\circ} 42^{\prime} 22^{\prime \prime}$ & $135^{\circ} 21^{\prime} 37^{\prime \prime}$ & Riprap seawall & \\
\hline 4 & Yagura Beach & $34^{\circ} 41^{\prime} 18^{\prime \prime}$ & $135^{\circ} 25^{\prime} 04^{\prime \prime}$ & Riprap seawall & Osaka Port* \\
\hline 5 & Juso delta & $34^{\circ} 43^{\prime} 09^{\prime \prime}$ & $135^{\circ} 29^{\prime} 43^{\prime \prime}$ & Gravel, block reinforcing both banks & \\
\hline 6 & Osaka Nanko Bird Sanctuary & $34^{\circ} 38^{\prime} 14^{\prime \prime}$ & $135^{\circ} 23^{\prime} 55^{\prime \prime}$ & Riprap seawall & \\
\hline 7 & Sakai No.2 landfill & $34^{\circ} 36^{\prime} 11^{\prime \prime}$ & $135^{\circ} 25^{\prime} 48^{\prime \prime}$ & Riprap and concrete seawall & Sakai-Senboku Port* \\
\hline 8 & Takashino-hama beach & $34^{\circ} 35^{\prime} 52^{\prime \prime}$ & $135^{\circ} 25^{\prime} 54^{\prime \prime}$ & Gravel, concrete seawall & \\
\hline 9 & Otsu River & $34^{\circ} 30^{\prime} 29^{\prime \prime}$ & $135^{\circ} 23^{\prime} 11^{\prime \prime}$ & Riprap seawall & Han-nan Port* \\
\hline 10 & Han-nan No.2 landfill & $34^{\circ} 28^{\prime} 45^{\prime \prime}$ & $135^{\circ} 21^{\prime} 37^{\prime \prime}$ & Riprap seawall & \\
\hline 11 & Mouth of Kogi River & $34^{\circ} 26^{\prime} 30^{\prime \prime}$ & $135^{\circ} 20^{\prime} 09^{\prime \prime}$ & Wave dissipating concrete block & \\
\hline 12 & Mouth of Kashii River & $34^{\circ} 23^{\prime} 35^{\prime \prime}$ & $135^{\circ} 16^{\prime} 39^{\prime \prime}$ & Riprap seawall & Izumi-sano Port \\
\hline 13 & Onosato River Delta & $34^{\circ} 22^{\prime} 37^{\prime \prime}$ & $135^{\circ} 15^{\prime} 00^{\prime \prime}$ & Gravel, Wave dissipating concrete block & \\
\hline 14 & Sen-nan Satoumi Park & $34^{\circ} 20^{\prime} 18^{\prime \prime}$ & $135^{\circ} 11^{\prime} 32^{\prime \prime}$ & Riprap seawall & Fuke Port \\
\hline 15 & Mouth of Higashi River & $34^{\circ} 19^{\prime} 19^{\prime \prime}$ & $135^{\circ} 07^{\prime} 11^{\prime \prime}$ & Gravel, block reinforcing both banks & \\
\hline 16 & Ohama Beach & $34^{\circ} 20^{\prime} 28^{\prime \prime}$ & $134^{\circ} 54^{\prime} 21^{\prime \prime}$ & Concrete jetty & \\
\hline
\end{tabular}

ried out in co-operation with many groups of environmentally aware civilians and scientists. The number of participants in the surveys varied from 820 to 1,011 per year and from 12 to about 200 per station. The surveys took between 2 to 3 hours at each station. Marine organisms living in the intertidal zone were recorded by visual observation by the participants during the surveys. Organisms that could not be identified immediately were collected or photographed and sent to the Osaka Museum of Natural History for identification by specialists. The stations that were surveyed only twice or less were excluded from our analysis. Therefore, we report herein on 16 stations that were surveyed every year between 2010 and 2013 (Fig. 1, Table 1). No surveys were undertaken subtidally, so exclusively subtidal introduced species such as Megabalanus coccopoma (Darwin) and Molgula manhattensis (De Kay) would be missed.

All 16 stations consist of artificial substrata including riprap seawalls, concrete seawalls or wave dissipating concrete blocks established on a sandy substrate (Table 1). Among the 16 stations, seven that are adjacent to ports and for which water quality data exist were chosen to evaluate the influence of water quality (i.e., temperature and salinity) and the number of arriving ships on the number of introduced species (larger open circles in Fig. 1).

\section{Sampling method}

The biological data in Osaka Bay, which are qualitative, are confined to presence/absence records of all species of marine and brackish fishes, invertebrate animals, macro-algae and vascular plants (see Ishida et al., 2015).

Using the presently current list of the introduced species in Japan (Iwasaki et al., 2004; Otani, 2012) as a reference standard, the number of introduced and cryptogenic species in Osaka Bay could be ascertained and counted every year.
To check the influence of water quality on the spatial distribution of the number of introduced species, the results of surveys of water quality in public waters carried out by local governments according to the Water Pollution Prevention Act were used. Among the water quality data, we used the annual mean water temperature and salinity of seven water quality stations between 2009 and 2012 (Hyogo Prefectural Government, 2010-2013, Osaka Prefectural Government, 2010-2013). The time lag between the period covered by the water quality data and that of the biological data can be explained because of the delay in publishing the official water quality data.

The extensive international shipping traffic entering Osaka Bay is likely to import the propagules of introduced species. To evaluate the influence of the shipping traffic on the number of introduced species, we used the number of ships arriving annually, including both international and domestic cargo ships, at seven ports between 2010 and 2013 (Ministry of Land, Infrastructure, Transport and Tourism, 2012-2015).

It is known that propagule supply depends on both hull fouling and ballast water (Fofonoff et al., 2003; Hewitt and Campbell, 2010). However, the majority of ships visiting the ports in Osaka Bay are container ships, general cargo ships and PCCs (Pure Car Carriers) that discharge relatively small amounts of ballast water. This means that the vector more responsible for the introduction of introduced species is assumed to be hull fouling (except for Limnoperna fortunei (Dunker), for which the vector is assumed to be other than shipping (e.g. Otani, 2004). Hence, it is possible to use the number of arriving ships instead of the actual volume of ballast water discharged, as a proxy for the supply of propagules in this instance.

\section{Data analysis}

Since the total number of people participating in the sur- 
Table 2. Introduced species recorded in Osaka Bay from 2010 through 2013. X indicates the occurrence of each species in the year.

\begin{tabular}{|c|c|c|c|c|c|}
\hline \multirow{2}{*}{ Phylum } & \multirow{2}{*}{ Species } & \multicolumn{4}{|c|}{ Year } \\
\hline & & 2010 & 2011 & 2012 & 2013 \\
\hline \multirow[t]{2}{*}{ Annelida } & Ficopomatus enigmaticus & $\mathrm{X}$ & $\mathrm{X}$ & $\mathrm{X}$ & $\mathrm{X}$ \\
\hline & Hydroides dianthus & & & $\mathrm{X}$ & $\mathrm{X}$ \\
\hline \multirow[t]{7}{*}{ Mollusca } & Crepidula onyx & $\mathrm{X}$ & $\mathrm{X}$ & $\mathrm{X}$ & $\mathrm{X}$ \\
\hline & Mytilus galloprovincialis & $\mathrm{X}$ & $\mathrm{X}$ & $\mathrm{X}$ & $\mathrm{X}$ \\
\hline & Perna viridis & $\mathrm{X}$ & $\mathrm{X}$ & $\mathrm{X}$ & \\
\hline & Limnoperna fortunei & & & $\mathrm{X}$ & \\
\hline & Xenostrobus securis & $\mathrm{X}$ & $\mathrm{X}$ & $\mathrm{X}$ & $\mathrm{X}$ \\
\hline & Mytilopsis sallei & $\mathrm{X}$ & $\mathrm{X}$ & $\mathrm{X}$ & $\mathrm{X}$ \\
\hline & Petricola cf. lithophaga & $\mathrm{X}$ & $\mathrm{X}$ & $\mathrm{X}$ & $\mathrm{X}$ \\
\hline \multirow[t]{7}{*}{ Arthropoda } & Amphibalanus amphitrite & $\mathrm{X}$ & $\mathrm{X}$ & $\mathrm{X}$ & $\mathrm{X}$ \\
\hline & Amphibalanus eburneus & $\mathrm{X}$ & $\mathrm{X}$ & $\mathrm{X}$ & $\mathrm{X}$ \\
\hline & Amphibalanus improvisus & $\mathrm{X}$ & $\mathrm{X}$ & $\mathrm{X}$ & $\mathrm{X}$ \\
\hline & Pyromaia tuberculata & & & $\mathrm{X}$ & \\
\hline & Carcinus aestuarii & $\mathrm{X}$ & $\mathrm{X}$ & $\mathrm{X}$ & $\mathrm{X}$ \\
\hline & Rhithropanopeus harrisii & $\mathrm{X}$ & & $\mathrm{X}$ & $\mathrm{X}$ \\
\hline & Number of species & 12 & 11 & 15 & 12 \\
\hline
\end{tabular}

veys differed among stations and also between years, these differences in the intensity of the survey might have affected the total number of species recorded. In order to investigate whether the number of species recorded was affected by the intensity, we applied a Spearman's Rank Correlation Coefficient between the number of species and the number of participants between 2010 and 2013. That test showed no correlation among them (Spearman's Rank Correlation Coefficient: $R s=0.11, p>0.05)$, meaning the former was not affected by the latter. Accordingly, when we examined the temporal and spatial changes of the number of introduced species, we did not take the influence of participants into account. We applied a Friedman Test to examine whether the numbers of introduced species differed between years.

For analyzing the differences in the number of introduced species between the survey stations, both cluster analysis and non-metric multi-dimensional scaling (NMDS) based on the mean number for each station for four years were used. In the former analysis, the survey stations were clustered by the group mean method, where distance between the assemblages was measured by Bray-Curtis Dissimilarity Index. The difference among assemblages was analyzed by the Analysis of Similarities (ANOSIM) test.

The generalized linear model (GLM) was used for analyzing the causes of the spatial changes between the stations.

The formula for this model is:

$$
E\left[y_{i}\right]=\exp \left(\beta_{0}+\sum_{i j=1}^{p} \beta_{i j} x_{i j}\right)
$$

where " $i$ " donates each station and $E\left[y_{i}\right]$ is the expected value of the response variable, namely, the number of introduced species. Since $y_{i}$ is count data, it is assumed to follow a Pois- son distribution. The commonly used link function is $\log \beta_{0}$ and $\beta_{i j}$ are coefficients. " $x_{i j}$ " are explanatory variables, " $j$ " is the member of explanatory variables, and " $p$ " is the number of explanatory variables. Referring to Wasson et al. (2005), Preisler et al. (2009) and Ruiz et al. (2013), we provided four explanatory variables. They are the number of arriving ships, water temperature, salinity, and the number of native species.

Before employing these explanatory variables in the GLM analysis, we checked for multicollinearity among them by the variance inflation factor (VIF) values. None of them showed multicollinearity with the value of less than 1.9. In considering the application of a Poisson distribution for GLM, we also checked for overdispersion. The results showed that overdispersion did not occur because the observed variances of the response variable corresponded to the expected variances by GLM were included in the confidence interval at $99 \%$ level of the model. This means that we could apply a Poisson distribution for the GLM analysis.

In this analysis, the minimum AIC (Akaike Information Criterion) model was obtained by removing the explanatory variables one by one from the full model. In considering the difference of AIC value between the models, with their difference of less than 1, we concluded that there was no substantial difference between them (See Sakamoto et al., 1983).

All the statistical analyses were performed using the statistical program $\mathrm{R}$, version 2.13.2.

\section{Results}

\section{Species diversity}

A total of 552 species-level taxa, including 75 macro-algae (i.e., 12 Chlorophyta, 19 Heterokontophyta and 44 Rhodophyta), two vascular plants, and 475 animals (i.e., 12 Cnidaria, 39 Annelida, 174 Mollusca, 119 Arthropoda, 18 Echinodermata, 89 Chordata, and 24 minor taxa), was recorded when the records from all the censuses were pooled (see Ishida et al., 2015). The vast majority (97.3\%) of these species were native to Japan. Only fifteen species $(2.7 \%)$ were introduced (Table 2). No species was discovered that could be considered as cryptogenic.

\section{Temporal occurrence}

The number of introduced species recorded varied from 11 to 15 (Table 2) between years. A Friedman Test revealed that the differences in the numbers of introduced species between years were not significant $\left(X^{2}=6.23, p>0.05\right)$ implying considerable consistency of the number of introduced species in Osaka Bay during the survey period.

\section{Spatial occurrence}

The mean number of introduced species within Osaka Bay varied between stations during the survey period (Fig. 2). Cluster and NMDS analyses were used to compare the variation between the 16 stations (Figs $3 \mathrm{a}, \mathrm{b}$ ). Both analyses exhib- 


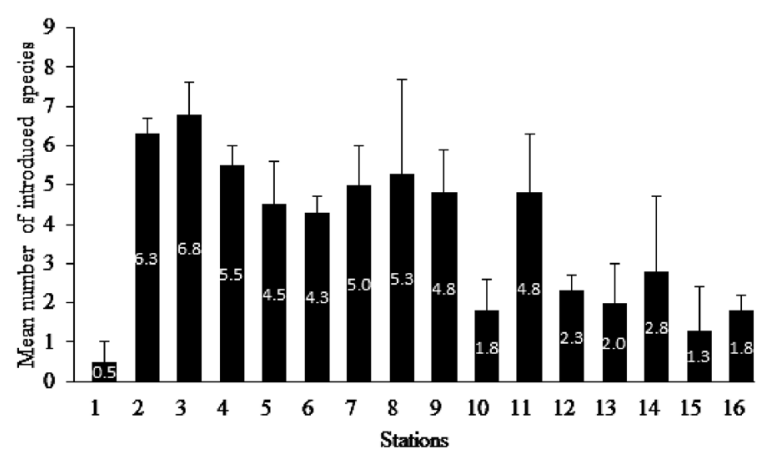

Fig. 2. Mean numbers of introduced species (numerals in vertical bars) for four years (2010-2013). Thin vertical bars indicate standard deviations.

(a)

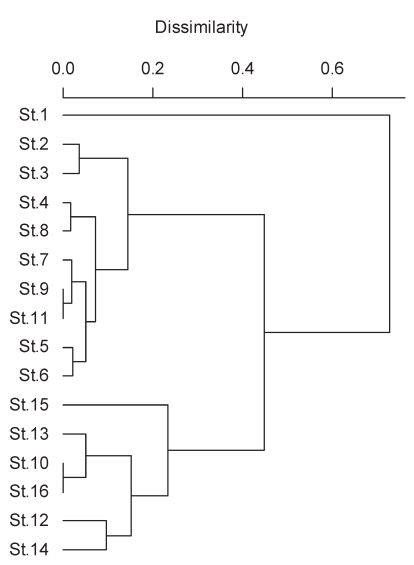

(b)

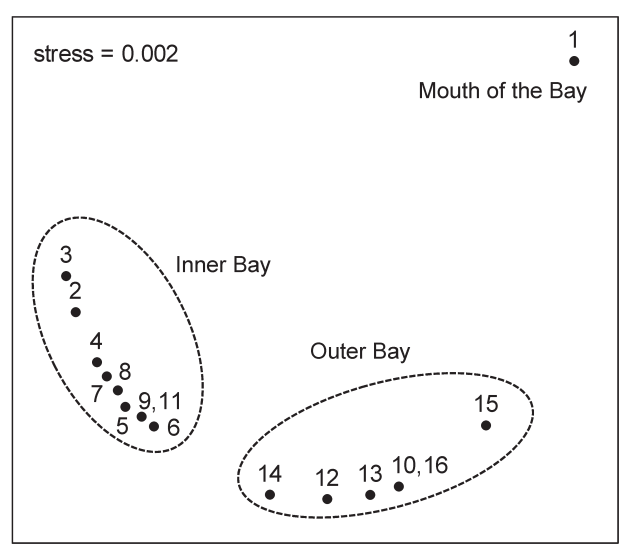

Fig. 3. Classification of the numbers of introduced species at 16 survey stations. (a); dendrogram by the group mean method, based on the mean number of introduced species. Distances between the stations were quantified by the Bray-Curtis dissimilarity index. (b); NMDS for sampling stations. Numerals show the survey stations indicated in Table 1 .

ited the same tendency. Namely, the stations were classified into three groups (ANOSIM test, $R=0.9855, p<0.01$ ): the inner Bay (Stations 2-9, 11) with the most species (4.3-6.8 species station $^{-1}$ ), the outer Bay (Stations 10, 12-16) with fewer species (1.8-2.8), and the mouth of the Bay (Station 1) with the fewest species of all (0.5) (Fig. 2).
Table 3. Results of GLM (Generalized Linear Model) analysis on the number of introduced species as a response variable. Explanatory variables are: number of arriving ships (Ship); water temperature (Wt); salinity (Sal) and number of native species (NS).

\begin{tabular}{ccccccc}
\hline & & & \multicolumn{4}{c}{ Coefficient } \\
\cline { 3 - 7 } Model & AIC & Intercept & \multicolumn{5}{c}{ Ship } & Wt & Sal & NS \\
\hline 1 & 114.3 & 2.16 & $2.7 \times 10^{-6}$ & 0.069 & -0.061 & -0.008 \\
2 & 112.4 & 2.58 & & 0.052 & -0.063 & -0.009 \\
3 & 110.5 & 3.53 & & & -0.061 & -0.009 \\
\hline
\end{tabular}

\section{Factors responsible for observed spatial dif- ferences}

As explained above, in response to the results of the significant spatial differences of the number of introduced species between the survey stations, we partitioned possible causes between temperature, salinity, number of arriving ships and the number of native species. Then we applied a GLM analysis to clarify the factors contributing to these differences.

Model 3 that included salinity and the number of native species was selected as the optimum prediction model with the smallest AIC (Table 3). This implies that salinity plus the number of native species contribute most greatly to the number of introduced species. The sign of the coefficients in the model showed that the salinity and the number of native species had a negative effect on the number of introduced species indicating that the more the former decreases, the more the latter tends to increase

\section{Discussion}

\section{Temporal persistence of introduced species}

The result of the long-term surveys of Osaka Bay revealed that the number of introduced species remained essentially unchanged during the survey period (i.e., those undertaken between 2010 and 2013). It is assumed that the same species accounted for the majority of the introduced species. Referring to Nabeshima (2007), when the period of investigation is extended back to 2007 , it is seen that the number of introduced species in Osaka Bay was actually constant for these seven years without any new introduced species being added (apart from the newly discovered L. fortunei) or lost. This finding runs contrary to the general picture of an everincreasing number of introduced marine species at particular localities (see Introduction).

\section{Spatial differences in numbers of introduced species}

The cluster analysis and NMDS indicated that Osaka Bay was able to be divided into three sectors, with the inner Bay supporting the greatest number of introduced species, the outer Bay supporting fewer introduced species, and the Bay's mouth supporting fewest of all (Fig. 3). Similar tendencies for the distributional pattern of the number of introduced spe- 
cies within a bay are also known from the North Sea (Reise et al., 1999), from Elkhorn Slough, California, United States of America (Wasson et al., 2005), and from other coasts globally (Preisler et al., 2009). Preisler et al. (2009) suggested that these differences could stem both from differences of propagule pressure and from differences of establishment rates after the introduction among areas.

The GLM analysis revealed that the factors that most affected the number of introduced species were salinity and the number of native species. The other two factors we investigated (i.e., the number of arriving ships and water temperature) did not affect the number of introduced species.

Ruiz et al. (2013) stated that the relationship between shipmediated propagule supply and invasion probability is expected to be density-dependent, increasing to an asymptote where environmental conditions are suitable for establishment. The levelling off of the number of introduced species at two sta-

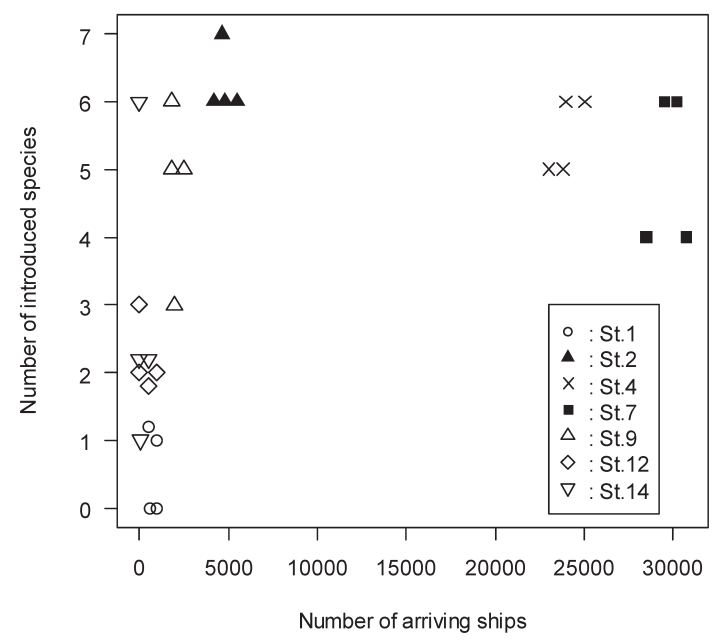

Fig. 4. Relationship between the number of introduced species and the number of arriving ships at seven survey stations in Osaka Bay. tions (4 and 7) in Osaka Bay (Fig. 4) seems to support this hypothesis. The increase to an asymptote at these stations in the inner Bay is thought to be caused by the competition between introduced species instead of a small number of native species there.

Neither was water temperature the factor affecting the number of introduced species in Osaka Bay. This is because the range of water temperatures experienced in Osaka Bay lies within the natural tolerance range of most of the introduced species (Fig. 5).

The salinity range in Osaka Bay was also within in the natural tolerance range of most of the introduced species (Fig. 6). This implies that most introduced species are capable of being distributed widely within the Bay. However, on the seven stations used in the GLM analysis, the distribution of six species (Xenostrobus securis (Lamarck), Carcinus aestuarii Nardo, Petricola sp., Ficopomatus enigmaticus (Fauvel), Perna viridis (Linnaeus) and Mytilopsis sallei (Récluz)) is limited almost solely to the inner Bay (Fig. 7). Though salinity by itself is not a limiting factor for their distributions, they were certainly restricted to the inner Bay. This implies that some factor other than salinity was operating as the limiting factor for their distribution. As shown in Table 3, the most likely candidate for the factor limiting their distribution is the number of native species.

It has been claimed that a locality with a high diversity of native species has a low diversity of introduced species (Paavola et al., 2005; Wasson et al., 2005; David et al., 2013); this is the ecosystem resistance hypothesis that argues that the strong biotic resistance afforded by native species counters the establishment of non-native species (Wasson et al., 2005). It seems that the six introduced species restricted to the inner

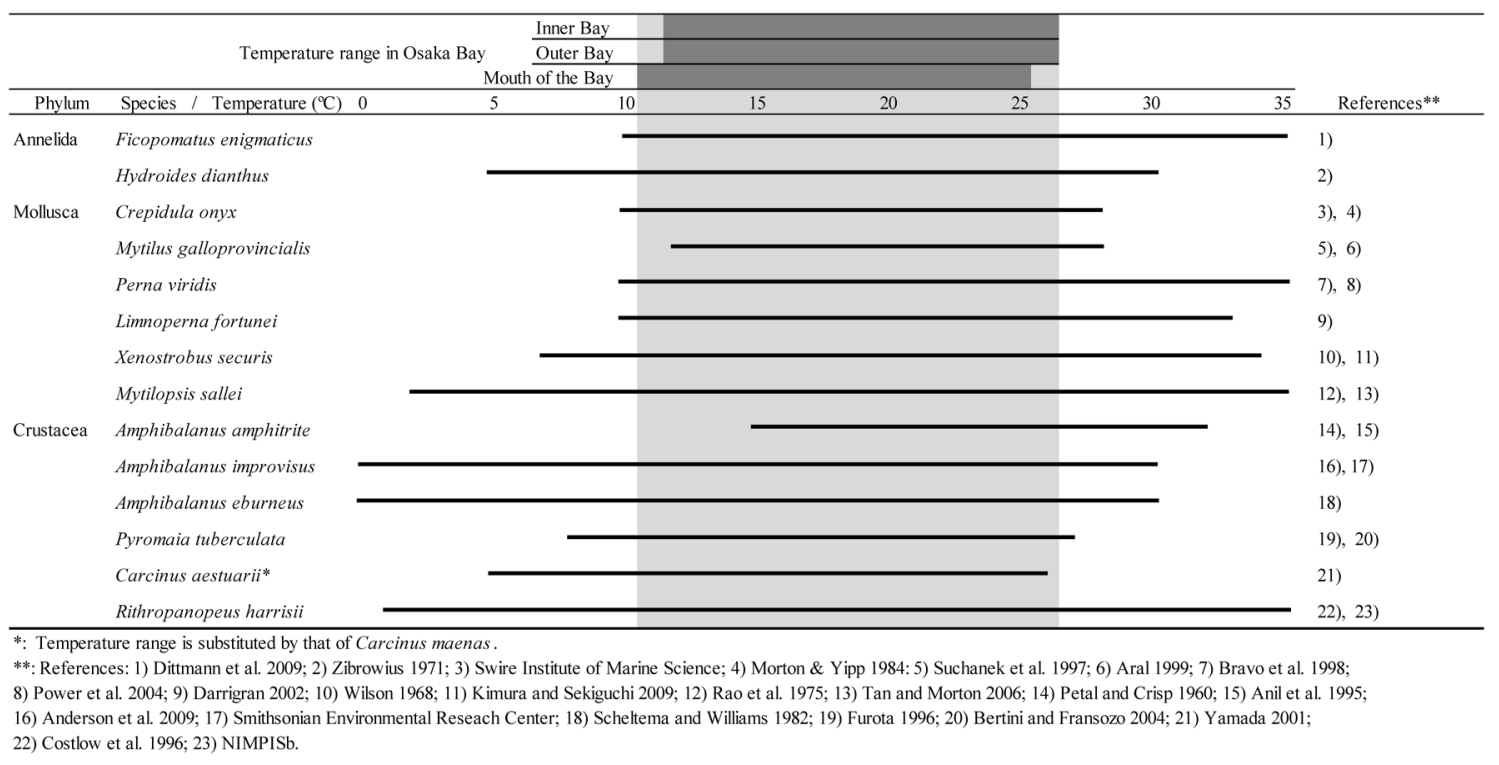

Fig. 5. Ranges of water temperature over which introduced species recorded in Osaka Bay have been reported to inhabit worldwide (horizontal bar). Light grey and dark grey zones show the temperature range of Osaka Bay and the temperature ranges for three regions in the Bay, respectively. 


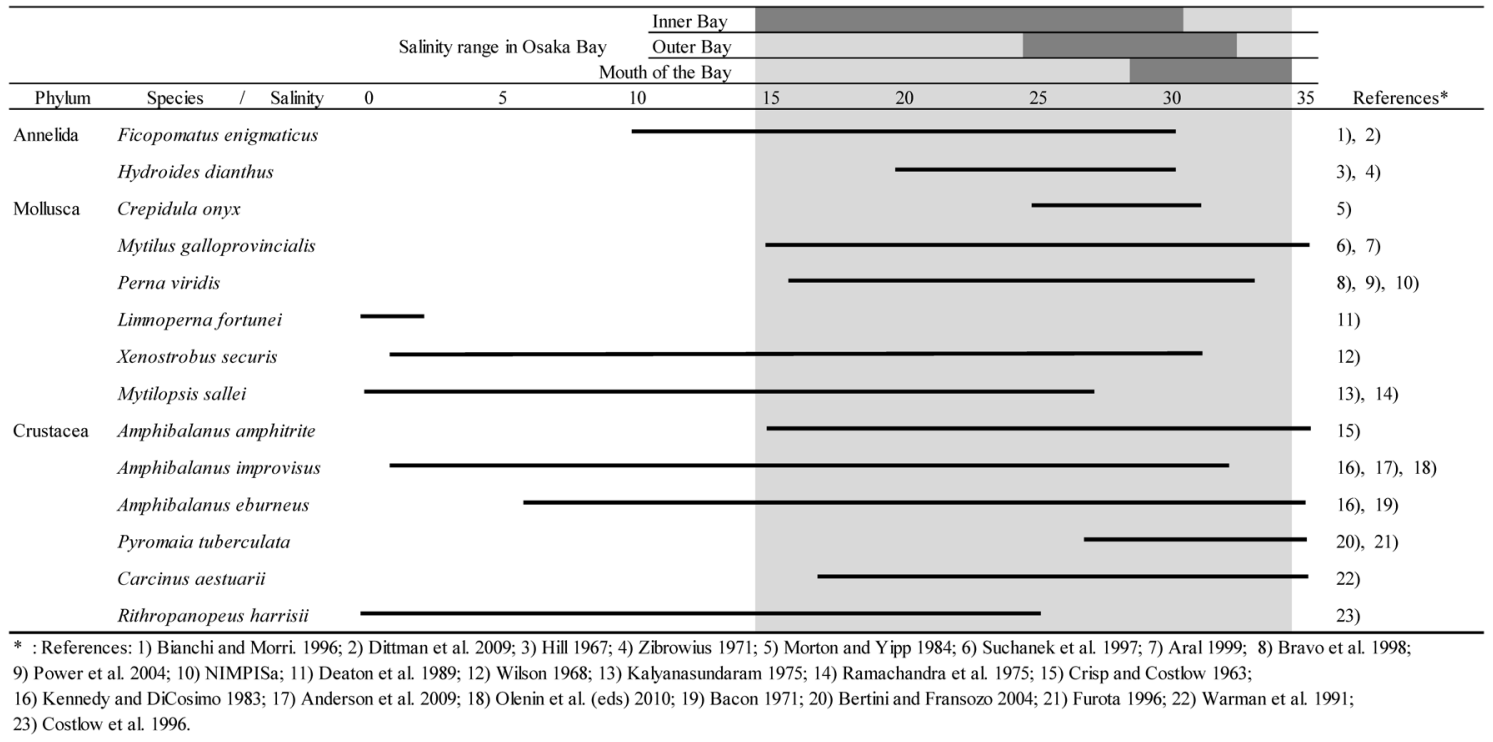

Fig. 6. Ranges of salinity over which introduced species recorded in Osaka Bay have been reported to inhabit worldwide (horizontal bar). Light grey and dark zones show the salinity range of Osaka Bay and the salinity range for three regions in the Bay, respectively.

\begin{tabular}{|c|c|c|c|c|c|c|c|c|}
\hline & \multicolumn{2}{|l|}{ Parts in the Bay } & \multicolumn{2}{|c|}{ Inner } & \multirow[b]{2}{*}{9} & \multicolumn{2}{|c|}{ Outer } & \multirow{2}{*}{$\begin{array}{c}\text { Mouth } \\
1\end{array}$} \\
\hline & Station & 2 & 4 & 7 & & 12 & 14 & \\
\hline Species & / Number of NS & 52 & 69 & 57 & 72 & 121 & 193 & 190 \\
\hline \multicolumn{9}{|c|}{ Amphibalanus amphitrite } \\
\hline \multicolumn{9}{|c|}{ Mytilus galloprovincialis } \\
\hline \multicolumn{9}{|c|}{ Amphibalanus eburneus } \\
\hline \multicolumn{9}{|c|}{ Amphibalanus improvisus } \\
\hline \multicolumn{9}{|c|}{ Crepidula onyx } \\
\hline \multicolumn{9}{|c|}{ Xenostrobus securis } \\
\hline \multicolumn{9}{|c|}{ Carcinus aestuarii } \\
\hline \multicolumn{9}{|c|}{ Petricola sp. } \\
\hline \multicolumn{9}{|c|}{ Ficopomatus enigmaticus } \\
\hline \multicolumn{9}{|c|}{ Perna viridis } \\
\hline \multicolumn{9}{|c|}{ Mytiopsis sallei } \\
\hline Pyromaia & tuberculata & & & & & & & \\
\hline
\end{tabular}

Fig. 7. Distribution pattern of 12 introduced species recorded at seven stations in Osaka Bay. Grey zones show the occurrence of each species at each station. 'Number of NS' indicates the number of native species recorded between 2010 through 2013 at each station. The six introduced species in the square are those whose distributions are mainly restricted to the inner Bay.

Bay would meet with stronger biotic resistance from native species in the outer Bay than in the inner Bay. The mode of biotic resistance differs according to the life type of the native species, depending on whether they are sessile, sedentary or mobile (Fofonoff et al., 2003). For example, as Stachowicz et al. (2002) have described, it is assumed that sessile animals and algae impose tight spatial restriction on introduced species depriving them of their habitats. Sedentary animals may have the same impact on introduced species as sessile types do. Furthermore, in addition to deprivation of habitat, it is also known that macro-algae limit the settlement of larvae of introduced species either by forming a physical barrier, or by reducing water circulation and mixing, or by whiplash action induced by waves (Lewis, 1964; Seed, 1969; Jenkins and Hawkins, 2003; Russell et al., 2008). As Jenkins and Hawkins
(2003) indicated, mobile animals would have limited the invasion and settlement of introduced species by directly preying upon them or by indirectly grazing them. Indeed, we assume each major group of organisms in Osaka Bay also possesses some properties that serve to block introduced species.

Not only biotic resistance, as described by Ling et al. (2012), but the abundance of prey available for the introduced species may also be an important factor limiting introductions. The type of prey must be different for every introduced species. Unfortunately, we could not clarify the importance of the quantity and the type of prey for the introduction because of the lack of the data related to the prey.

\section{Future research and conclusions}

Though the long-term data indicate a strong temporal persistence of introduced species in Osaka Bay and our statisti- 
cal analyses for verifying spatial differences indicate this is most probably determined by the number of native species, we were not able to evaluate the practical contribution that the native species actually make towards the prevention of invasion by introduced species through competitive exclusion and predation. This is because the data were limited to just the presence/absence of the species themselves. Ideally a more detailed quantitative field survey underpinned by a more rigorous experimental approach should be taken to investigate the relationships of the native and introduced species.

Furthermore, it is also necessary to investigate biotic interactions between the introduced species themselves. At some stations in the inner Bay where less native species were found, the number of introduced species has apparently levelled off in time in spite of ongoing heavy shipping traffic. This implies that competition for space or predation between the introduced species themselves might be a controlling factor. Such competition and predation, as we have predicted to occur in the inner Bay, between introduced species should be verified.

It is also necessary to advance studies for identifying the areas most prone to invasion by clarifying the invasion mechanism itself based on the understanding of the quantitative relationship between the native species and the introduced species, and between the introduced species themselves. Without such studies, it is impossible to forestall future introductions and to take countermeasures to prevent the damage caused by introduced species.

Baseline studies are also necessary for early detection of introduced species. Annual surveys of intertidal organisms carried out by numerous observers are one example of ways such basic information can be accumulated. The continuation of these surveys will also play an important monitoring function for future introductions.

\section{Acknowledgements}

The authors would like to thank the participants from all the surveys for collecting the data on introduced marine organisms. We thank Dr M. Yokogawa (Osaka Museum of Natural History) for his helpful advice on statistical analyses. We are also grateful to Dr K. Iwasaki (Nara University), Dr S. Ishida (Osaka Museum of Natural History) and Dr J. Chapman (Oregon State University, Oregon, USA) for their useful comments and suggestions on an earlier draft of this paper.

\section{Literature Cited}

Anderson, M. H., M. Berggen, D. Wilhelmsson and M. C. Öhman (2009). Epibenthic colonization of concrete and steel pilings in a cold-temperate embayment: A field experiment. Helgol. Mar. Res., 63, 249-260.

Anil, A. C., K. Chiba, K. Okamoto and H. Kurokura (1995). Influence of temperature and salinity on larval development of Balanus amphitrite: Implications in fouling ecology. Mar. Ecol. Prog. Ser., 118, 159-166.

Aral, O. (1999). Growth of the Mediterranean mussel (Mytilus galloprovincialis Lam., 1819) on ropes in The Black Sea, Turkey. Turk. J. Vet. Anim. Sci., 23, 183-189.

Bacon, P. R. (1971). The maintenance of a resident population of Balanus eburneus (Gould) in relation to salinity fluctuations in a Trinidad Mangrove Swamp. J. Exp. Mar. Biol. Ecol., 6, 187-198.

Bertini, G. and A., Fransozo (2004). Bathymetric distribution of brachyuran crab (Crustacea, Decapoda) communities on coastal soft bottoms off southeastern Brazil. Mar. Ecol. Prog. Ser., 279, 193-200.

Bianchi, C. N. and C., Morri (1996). Ficopomatus 'reefs' in the Po river delta (Northern Adriatic): Their constructional dynamics, biology, and influence on the brackish-water biota. Mar. Ecol., 17, 51-66.

de Bravo, M. J., K. S. Chung and J. E. Pérez (1998). Salinity and temperature tolerances of the green and brown mussels, Perna viridis and Perna perna (Bivalvia: Mytilidae). Rev. Biol. Trop. Suppl., 5, 121-125.

Cohen, A. N. and J. T., Carlton (1998). Accelerating invasion rate in a highly invaded estuary. Sci., 279, 555-558.

Costlow, J. D., C. G. Jr. Bookhout and R. J. Monroe (1966). Studies on the larval development of the crab Rhithropanopeus harrisii (Gould). I. The effect of salinity and temperature on larval development. Physiol. Zool., 39, 81-100.

Crisp, D. J. and J. D., Costlow (1963). The tolerance of developing cirripede embryos to salinity and temperature. Oikos, 14, 23-34.

Darrigran, G. (2002). Potential impact of filter-feeding invaders on temperate inland freshwater environments. Biol. Invasions, 4, $145-156$.

David, M., S. Gollasch and E. Leppäkoski (2013). Risk assessment for exemptions from ballast water management - The Baltic Sea case study. Mar. Pollut. Bull., 75, 205-217.

Deaton, L. E., J. G. S. Derby, N. Subhedar and M. J. Greenberg (1989). Osmoregulation and salinity tolerance in two species of bivalve mollusc: Limnoperna fortunei and Mytilopsis leucophaeta. J. Exp. Mar. Biol. Ecol., 133, 67-79.

Dittmann, S., A. Rolston, S. N. Benger and E. K. Kupriyanova (2009). Habitat requirements, distribution and colonisation of the tubeworm Ficopomatus enigmaticus in the Lower Lakes and Coorong. Report for the South Australian Murray-Darling Basin. Natural Resources Management Board, Adelaide, pp $1-99$.

Elton, C. (1958). The ecology of invasion by plants and animals. Methuen and Co., London, 196 pp.

Fofonoff, P. W., G. M. Ruiz, B. Steves and J. T. Carlton (2003). In ships or on ships? Mechanisms of transfer and invasion for nonnative species to the coasts of North America. In: Invasive species: Vectors and management strategies, eds. G. M. Ruiz and J. T. Carlton, Island Press, Washington, pp. 152-182.

Furota, T. (1996). Life cycle studies on the introduced spider crab Pyromaia tuberculata (Lockington) (Brachyura: Majidae) II. Crab stage and reproduction. J. Crustac. Biol., 16, 77-91.

Hayes, K. R. (2003). Biosecurity and the role of risk assessment. In: Invasive Species: Vectors and Management Strategies, eds. G. M. Ruiz and J. T. Carlton, Island Press, Washington, pp. 382413.

Hewitt, C. and M., Campbell (2010). The relative contribution of vectors to the introduction of invasive marine species. Report for the Department of Agriculture, Fisheries and Forestry of Australia by the National Centre for Marine Conservation and Resources Sustainability, Australian Maritime College, Australia, pp. 1-55.

Hill, M. B. (1967). The life cycles and salinity tolerance of the serpulids Mercierella enigmatica Fauvel and Hydroides uncinata 
(Philippi) at Lagos, Nigeria. J. Anim. Ecol., 36, 303-321.

Horiguchi, T. (1995). Heterocapsa circularisquama sp. nov. (Peridiniales, Dinophyceae): A new marine dinoflagellate causing mass mortality of bivalves in Japan. Phycol. Res., 43, 129-136.

Hyogo Prefectural Government (2009-2012). Annual report of the water quality of public waters, Fiscal Year 2008 to 2011. Hyogo Prefectural Government, Japan. (in Japanese)

Ishida, S., M. Otani, Y. Nabeshima, R. Yamanishi and T. Watanabe (2015). Report on biological survey in Osaka Bay. The Committee for Biological Surveys in Osaka Bay, pp.1-38. (in Japanese)

Iwasaki, K., T. Kimura, K. Kinoshita, T. Yamaguchi, T. Nishikawa, E. Nishi, R. Yamanishi, I. Hayashi, K. Okoshi, T. Kosuge, T. Suzuki, Y. Henmi, T. Furota and H. Mukai (2004). Human-mediated introduction and dispersal of marine organisms in Japan: Results of a questionnaire survey by the Committee for the Preservation of the Natural Environment. Jpn. J. Benthol., 59, 22-44, in Japanese with English abstract.

Jenkins, S. R. and S. J., Hawkins (2003). Barnacle larval supply to sheltered rocky shores: A limiting factor? Hydrobiol., 503, 143151.

Kalyanasundaram, N. (1975). Studies on the biology of Mytilopsis sallei (Recluz), an important marine fouling mollusc. Bull. Dept. Mar. Sci. Cochin. Univ., 7, 685-693.

Kennedy, V. S. and J., DiCosimo (1983). Subtidal distribution of barnacles (Cirripedia: Balanidae) in Chesapeake Bay, Maryland. Estuaries, 6, 95-101.

Kimura, T. and H., Sekiguchi (2009). Spatial and temporal patterns of abundance of the exotic mytilid Xenostrobus securis and the native mytilid Musculista senhousia in the Lake Hamana, Japan. Marine Biodiversity Records, 2, e89, 1-7.

Ling, S. D., C. R. Johnson, C. N. Mundy, A. Morris and D. J. Ross (2012). Hotspots of exotic free-spawning sex: man-made environment facilitates success of an invasive seastar. J. Appl. Ecol., 49, 733-741.

Lewis, J. R. (1964). The ecology of rocky shores. English University Press, London, 323 pp.

Ministry of Land Infrastructure, Transport and Tourism (2012-2015). Annual report of port's statistics, Fiscal Year 2010 to 2013. Ministry of Land, Infrastructure, Transport and Tourism, Japan. (in Japanese)

Morton, B. and M. W., Yipp (1984). The distribution and ecologicalbiological features of Crepidula onyx in Hong Kong. Acta Oceanol. Sin., 3, 263-275.

Nabeshima, H. (2007). Latest trends and appearance of introduced marine organisms in Osaka Bay and Seto Inland Sea. Aquabiol., 29, 236-247, in Japanese with English abstract.

Nature Conservation Bureau of the Environment Agency (1998). Report for the seashore survey of the 5th National Survey on the Natural Environment. Nature Conservation Bureau of the Environment Agency, Japan. (in Japanese)

NIMPISa (Australian national introduced marine pest information sheet) http://data.daff.gov.au/marinepests/index.cfm?fa = main. spDetailsDB\&sp $=6000010430$, searched on 22 January 2014.

NIMPISb (Australian national introduced marine pest information sheet) http://data.daff.gov.au/marinepests/index.cfm?fa=main. spDetailsDB\&sp $=6000011427$, seached on 22 January 2014.

Olenin, S., D. Daunys, E. Leppäkoski and A. Zaiko (eds) (2010). Baltic Sea alien species database. http:/www.corpi.ku.lt/nemo/ balanus.html, searched on 15 January 2014.

Osaka Prefectural Government (2009-2012). Annual report of the water quality of public waters, Fiscal Year 2008 to 2011. Osaka Prefectural Government, Japan. (in Japanese)

Otani, M. (2004). Introduced marine organisms in Japanese coastal waters, and the processes involved in their entry. Jpn. J. Benthol., 59, 45-57, in Japanese with English abstract.

Otani, M. (2012). Introduced marine and brackish organisms in Japanese coastal waters, and the processes underlying their introduc- tion. Proceedings of the regional workshop on marine invasive species problem in the Northwest Pacific, DINRAC, Quingdao, China.

Paavola, M., S. Olenin and E. Leppäkoski (2005). Are invasive species most successful in habitats of low native species richness across European brackish water seas? Estuar. Coast. Shelf Sci., 64, 738-750.

Petal, B. and D. J., Crisp (1960). Rates of development of the embryos of several species of barnacles. Physiol. Zool., 33, 104-119.

Power, A. J., R. L. Walker, K. Payne and D. Hurley (2004). First occurrence of the nonindigenous green mussel, Perna viridis in coastal Georgia, United States. J. Shellfish. Res., 23, 741-744.

Preisler, R. K., K. Wasson, W. J. Wolff and M. C. Tyrrell (2009). Invasions of estuaries vs adjacent open coast: A global perspective. In: Biological invasion in marine ecosytems, eds. G. Rilov and J. A. Crooks, Springer-Verlag, Berlin, pp. 587-617.

Ramachandra, R. P., R. K. Mangpathi, S. S. Ganti and N. Kalyanasundaram (1975). Effect of extreme salinity conditions on the survival of Mytilopsis sallei Recluz (Pelecypoda). Hydrobiol., 46, 199-206.

Rao, K. M., P. R. Raju, S. S. Ganti and N. Kalyanasundarum (1975). Metabolism in Mytilopsis sallei (Recluz) (Pelecypoda): Influence of temperature. Curr. Sci., 44, 110-112.

Reise, K., S. Gollasch and W. J. Wolff (1999). Introduced marine species of the North Sea coasts. Helgol. Meeresunters., 52, 219-234.

Ruiz, G. M., P. W. Fofonoff, G. Ashton, M. S. Minton and A. W. Miller (2013). Geographic variation in marine invasions among large estuaries: effects of ships and time. Ecol. Appl., 23, 311320.

Russell, L. K., C. D. Hepburn, C. L. Hurd and M. D. Stuart (2008). The expanding range of Undaria pinnatifida in southern New Zealand: Distribution, dispersal mechanisms and the invasion of wave-exposed environments. Biol. Invasions, 10, 103-115.

Sakamoto, S., M. Ishiguro and G. Kitagawa (1983). Information criterion statistics. Kyoritsu Shuppan, Tokyo, pp. 236. (in Japanese)

Sato, Y., T. Oda, T. Muramatsu, Y. Matsuyama and T. Honjo (2002). Photosensitizing hemolytic toxin in Heterocapsa circularisqua$m a$, a newly identified harmful red tide dinoflagellate. Aquatic. Toxicol., 56, 191-196.

Scheltema, R. and I., Williams (1982). Significance of temperature to larval survival and length of development in Balanus eburneus (Crustacea: Cirripedia). Mar. Ecol. Prog. Ser., 9, 43-49.

Seed, R. (1969). The ecology of Mytilus edulis L. (Lamellibranchiata) on exposed rocky shores. I. Breeding and settlement. Oecol., 3, 277-316.

Smithsonian Environmental Research Center (2015). http://invasions. si.edu/nemesis/browseDB/SpeciesSummary.jsp?TSN=89621, searched on 13 April 2015.

Stachowicz, J. J., H. Fried, R. W. Osman and R. B. Whitlatch (2002). Biodiversity, invasion resistance, and marine ecosystem function: reconciling pattern and process. Ecol., 83, 2575-2590.

Suchanek, T. H., J. B. Geller, B. R. Kreiser and B. Mitton (1997). Zoogeographic distribution of the sibling species Mytilus galloprovincialis and M. trossulus (Bivalvia: Mytilidae) and their hybrids in the North Pacific. Biol. Bull., 193, 187-194.

Swire Institute of Marine Science (2014). http://www.swims.hku.hk/ nonnative $\% 20$ webpage/crepidula.dwt, searched on 22 January 2014.

Tan, K. S. and B., Morton (2006). The invasive Caribbean bivalve Mytilopsis sallei (Dreissenidae) introduced to Singapore and Johor Bahru, Malaysia. Raffles Bull. Zool., 54, 429-434.

Warman, C. G., P. Abelló and E. Naylor (1991). Behavioural responses of Carcinus mediterraneus Czerniavsky, 1884 to changes in salinity. Sci. Mar., 55, 637-643.

Wasson, K., K. Fenn and J. S. Pearse (2005). Habitat differences in marine invasions of central California. Biol. Invasions, 7, 935- 
948.

Wilson, B. R. (1968). Survival and reproduction of the mussel Xenostrobus securis (Lam.) (Mollusca: Bivalvia: Mytilidae) in a Western Australian estuary. Part I Salinity tolerance. J. Nat. Hist., 2, 307-328.

Wolff, W. J. (1999). Exotic invaders of the meso-oligohaline zone of estuaries in the Netherlands: Why are there many? Helgol.
Meeres., 52, 393-400.

Yamada, S. B. (2001). Global invader: The European green crab. Oregon State University, Oregon, $123 \mathrm{pp}$.

Zibrowius, H. (1971). Les espèces Méditerranéene du genre Hydroides (Polychaeta Serpulidae). Remarques sur le prétendu polymorphisme de Hydroides uncinata. Téthys, 2, 691-745. 